\title{
CONSUMPTION PRATICE IN THE BAUDRILLARD PERSPECTIVE
}

\author{
Purwanti Silviana ${ }^{1 *}$, Mas'ud Mustain ${ }^{2}$ \\ ${ }^{1}$ Student, Postgraduate Program, University of Airlangga \& Lecturer, Faculty of Social \\ and Political Science, University of Mulawarman, Samarinda, Indonesia \\ ${ }^{2}$ Head of Study Program, Postgraduate Program, University of Airlangga, Surabaya, \\ Indonesia \\ *E-mail: silviunmul123@gmail.com
}

\begin{abstract}
This research is a review of consumption practice with the underlying assumption of advanced post-industrial capitalist or postmodern as the consumptive society. This research tries to review the consumption practice and pattern of material goods or symbolic activity. Consumption in this research is the whole type of social events done by everyone so that the operation can be used to characterize and recognize him. The effort to acquire the knowledge on consumption practice of the modern society also includes the debate on a more philosophical epistemological aspect of the 'modernity'or even 'postmodernity' terminologies. Consumption, in Baudrillard, is radicalized into the consumption of sign. It means that the consumption society is no longer bound to a morality and habit they once held, but they see the existence from the aspect of how many signs they can consume. In this kind of society, consumption is no longer seen as an activity to consume the object but as a systematic action to manipulate the object. The consumption referred to in this study is no longer of use (usability) or exchange value but more about symbolic value. Consumption rationality diverted its path as an effort to fulfill desire instead of needs. This research also uses the qualitative approach of phenomenology. The subject of this study is the members of Ganbattearisangroup (regular revolving savings social gathering) in Samarinda consist of 10 upper-middle-class women who work as entrepreneur and professional. This research uses an approach in the cultural perspective as a way of life in reviewing a problem.
\end{abstract}

\section{KEY WORDS}

Arisan, Baudrillard, consumption, qualitative approach, culture, consume.

This research is a review of consumption practice with the underlying assumption of advanced post-industrial capitalist or postmodern as the consumptive society (Featherstone, 2001; Ritzer, 2012). The term 'consumptive society' refers to the condition where the practice has, uses, and spends the value of a product done by human become a significant activity with a particular socio-cultural meaning. Referring to Baudrillard in his book titled Consumption Society (2004) one of the phenomena in the consumption society that what we are consuming is a sign (message, image) rather than a commodity. It means that we need to "read" the consumption system to know what to consume. Furthermore, we all know that the "code" of the meaning of consumption of a commodity over another. This research turns arisan of women in the city in Samarinda, as the subject of the study.

Referring to the thought of Mark Patterson (2006) on consumption in everyday life, consumption is not a new thing, but the birth of a consumer society is a matter of debate. How about the time when Queen Elizabeth who highlighted the nobility status of the fashionable and new dress. The consumer society appears in the modern sense; there are two general things to note. First, the emergence of the consumer society occurs in all phases of capitalism, even in the early stage. Second, every time the 'modern' consumption indeed happens, whether in the sixteenth, seventeenth, eighteenth or nineteenth centuries. We assume that the birth of consumer society is destroying workers and what is being produced. In short, the emergence of consumer society is often seen as something negative, unnatural and inharmonious, causing damage to the relativity and injecting alienation between producer and product. 
In this study, the researcher tries to review the consumption practice and pattern of material goods or symbolic activity. Consumption in this research is the whole type of social events done by everyone so that the action can be used to characterize and recognize him. The activity here includes the practice of spending the time in his way so that it has its meaning for him. The object of the consumption as a symbolic form indicating "who I am" or self-status found by consuming a product where its outer image can elevate his identity.

This topic is considered necessary because the practice of consumption is not only happening in big cities like Jakarta, Surabaya, and others, which is often referred to as the 'orientation' of lifestyle. This phenomenon also occurs in a small town such as Samarinda which becomes the location of the research in this paper. It can be identified with the development of news in the media social about the lifestyle of the local community. As reported by Tempo online, a woman named Amelia Masniari or Miss Jinjingclaimes herself as the lifestyle expert. She often tells about the lifestyle of new rich (OKB) in the inland of Indonesia and these people do not live in Jakarta or Java Island, but they live in inland, in a new regency and city of Indonesia.

"...there are a lot of new rich come from rural areas of Indonesia. At first, she was surprised by the request of 2,000 books with the price of Rp. 178 thousand per-exemplar. The result of multiplying the price of the book and the number of requests is quite fantastic. And what makes it more fantastic is that the consumer paid it in cash. What's more confusing is that the delivery of the books she wrote addressed to rural areas with the uncommon names such as Nunukan, Pulau Rote, Kutai, Luwuk or other inlands with mining, wood and others type of business. Some of the inhabitants own luxury cars such as Jaguar, Lamborghini, and others, although they live in rural area. Furthermore, some houses have its private jet area. Most of them are low profile; they don't act like celebrity or socialite who likes to show off in media social. They don't have the urge to be popular because of the money, and the reason is that in the social circle they are already popular. Miss Jinjing also tells that there are a lot of new rich from inland who like to bring cash both in rupiah and dollar to do any transaction. Not to mention to pay branded bag, luxury car, diamond jewelry, and even property such as home and apartment. According to the Miss Jinjing community, they (new rich in inland) buy property and land in Jakarta with corrupting price because they are bold enough to pay a higher price and in cash comparing to rich people in Jakarta and Java Island who mostly pay through credit. Another fact is that if the former new rich usually come to community health center, most of them now like to fly to Singapore, Australia, China and Europe even when they only have a cough. What's more interesting from this phenomenon is that the number of the world-class diamond shop such as Frank \& Co, Felice, D\&C trying to sneak in the rural areas, to come to the consumer of new rich and sell their diamonds there. Most of them are selling very well like selling hotcakes, and most of the costumers pay in cash with rupiah or dollar. The presence of outlet in Jakarta is just a storefront. The reason is that most of their actual consumers are the new rich living in the inland. Miss Jinjing also wrote about several new rich communities who live in inland and owning Lexus, Land Cruiser, Jaguar and other luxury cars and even jet. However, they chose these type of cars not to show off but to support their business, so it has functional nature instead of showing off. The reason is that they don't need to show off to others, they have unlimited money and wealth..." (Tempo, 06/08/2014).

The consumption value practice of similar marks of the above exposure is also indicated in the Ganbattearisan group, the arisan group that the participants are the women of the upper middle class and the research location in this study is in the city of Samarinda. In Indonesia, Arisan is like a social gathering, usually done by housewives or female members of a community. Arisan becomes the medium for women to gather, share stories and as means to "save money" in different ways. Arisan is usually formed by profession, family relationship, age hobby, and others. Thus, in connection with this study, the contradictive development patterns fill in both social and cultural change and exhibit powerful influencers with so-called global models of society's life and become the global culture, to the point in which they accept the way of life, the lifestyle and life perspective. On the other hand, 
it has threatened the existence of various forms of traditional inheritance, customs, values, identities and symbols derived from local culture.

The act of determining Samarinda as the research location cannot be separated from the fact that Samarinda is the most expensive city in East Kalimantan and it's the ninth major city in Indonesia. It is not surprising because the consumption pattern of community in Rural Area is quite high. Starting from the seafood, new gadget to luxury car become the hunting objects of the upper-middle-class society.

It can be interpreted that the consumption community puts meaning in themselves by differentiating its consumption activity with others. Ironically, the purpose of the sign consumed by the individual is not derived from the value of the commodity he or she has consumed, but through its sign system and develop a culture. In this study, the researcher wants to know what kind of identity presented by Ganbattearisan group to show its existence and how the consumption practice and lifestyle of Ganbattearisan group in the Baudrillard's perspective.

The result of the early observation of the material object in this research is that the arisan group in Samarinda named Ganbatte referring to Soekanto (1987) that this group belongs to the upper-middle-class consisting of entrepreneur and professional.

The concept model used as the subject of this study is the concept of arisan utilized for 'identification' of this group. The members of this arisan are hard working women, thinker with good social interaction skills. This arisan started since January 2012, initiated by Dr. ME, Assistant I Provincial Government, the initial members amounted to 10 people, and now they have 15 members. However, they have a different concept of arisan, unlike a collection of beautiful women who like to lend money from their husband. This arisan consist of hardworking women, thinker with good social interaction skills. They also call it as Ganbattearisan group. Japanese school teachers often speak this word by the end of the lesson. The word "GANBATTE" means "SPIRIT," although most of Indonesian often use "CAYO!!!" Ganbatte can be translated to "Never Give Up," and it has profound meaning. Spirit is a picture where human still have a life expectancy, hope to struggle, to survive in daily life. Japanese school teachers often say it to encourage their students to keep studying and never give. This is in line with the spirit of the members of Ganbattearisan consisting of women with full of enthusiasm in each of their field. This social gathering can only be held once a month because most of the members are very busy. The members will pick the date between 10 and 11 every month depending on the availability of the members. They always hold this social gathering in Boncafe, Samarinda to honor the social interaction in arisan. Also, they will have specific dress code every month according to the agreement.

One of the arisan groups that will be analyzed in this research is Ganbattearisan group. For the members of this group, fashion is one of the ways to show their constructed class of identity and fashion can also have political sense. It means that one of the ways used to show positions and class of identities. In their opinion, fashion cannot be separated from the development of history of human life and culture. The importance of fashion in social context becomes more explicit about the status itself. Besides, clothing is an expression of personal identity, thus "selecting clothes either in-store or at home, means defining and describing ourselves" (Lurie, 1992: 5). For example, the recent event in Samarinda titled "Festival KemilauSarungSamarinda" where Ganbatte became the only arisan group to be awarded as a group that has helped to preserve the Samarinda culture.

The upper class used to consume an excessive amount to distinguish themselves from the lower levels of the social hierarchy. Meanwhile, the lower classes try to imitate the upperclass lifestyle. However, when the lower classes manage to emulate the objects of upperclass status, then those who are in upper class will try to remove those objects and seek for new objects to distinguish themselves from the lower classes. (Veblen in Ritzer, 2014)

The problem is that what kind of identity expected by the Ganbattearisan group to show its existence and how the consumption practice and lifestyle of Ganbattearisan group in the Baudrillard's perspective. Piliang (2004:150) recommends that the use of Jean Baudrillard's perspective to understand consumption in relation to the consumption practice and lifestyle will form individual or group identity that always disseminate and create signs to be 
consumed by the consumption society so that it can no longer distinguish between truth and fake or issue and reality. According to Baudrillard, consumption is radicalized into consumption of sign. This means that the consumption society is no longer bound to a morality and habit they once held, the community lives in new culture where they see the existence from the aspect how many signs they can consume. In this kind of society, consumption is no longer seen as an activity to consume the object but as systematic action to manipulate the object.

Baudrillard's theory of the Consumption Society. Baudrillard, argues that at this moment we have entered the life of postmodern and we are no longer in the era of existing modernity. This is marked by the concept of "simulation of society." The simulation process leads to simulacra. Simulacra can be interpreted as space where the simulation mechanism takes place. Referring to Baudrillard, there are three levels in the simulacra process (Baudrilard, 1983:54). The first simulacra that took place in the era of renaissance until the beginning of the industrial revolution. Simulacra in this stage are the representation of the natural relationship of various elements of life. Second, the simulacra that go along with the development of industrialization era. At this level, there has been a shift in the mechanism of representation due to the adverse impact of industrialization. The third stage, simulacra is born as a consequence of the development of science and information technology.

In term of simulation, humans inhabit a reality, where the difference between real and fantasy, between original and fake are very slim. These worlds can be illustrated as Disneyland, universal studio, China Town, Las Vegas and Beverly Hills. The world of simulation looks perfect through media information such as advertising, television, and film. The world of simulation can then be said to be no longer concerned with the reality or categories of truth, deceit, right, wrong, reference, representation, fact, image, production or reproduction merged into the chaos of sign. Besides, it cannot be separated from authentic and false. In the end, it becomes part of the reality which is lived by western society today. This unit is then called as simulacra by Baudrillard; it means a world constructed from the mixing of value, fact, sign, image, and code.

The Baudrillard's concept of simulation is about the creation of reality through the conceptual model or something related to "myth" which cannot be seen in reality. This model becomes the determinant factor of our perspective of reality. Everything that attracts people's attention - such as art, house, household needs and so on - are projected through various media with ideal models. Here, the boundary between simulation and reality mix up creating a hyperreality where real and imaginary become unclear.

In Ritzer (2003:164) Simulation is conceptually a creation of models of reality without the reference to reality. As well as hyperreality, Baudrillard views the era of simulation as part of series of evolving phase of images.

Simulation is different from the representation. Representation presupposes the existence of an unseparated relation between the sign and the reality of the reference. Representation is a symbol or sign that serves as the presentation of reality. Representation re-represents the reality in another appearance; meanwhile, the simulation represents another appearance as reality. It serves as a sign in the representation of an object, but it serves as an object in the simulation of the sign. In the simulation, there is no re-imagery of reality. Simulation forms a camouflage of reality to serve as a real-factual (Suyanto 2013: 208).

In the Consumer Society, Jean Baudrillard outlines how consumers buy into the "code" of signs rather than the meaning of the object itself. His analysis of the process by which the sign ceases pointing towards an object or signified which lies behind it, but rather to other signs which together constitute a cohesive yet chaotic "code", culminates in the "murder of reality". The rupture is so complete, the absence so resounding, and the code so "totalitarian" that Baudrillard speaks of the combined "violence of the image" and "implosion of meaning". Politics, religion, education, any human undertaking is swept up and absorbed by this process and ultimately neutralized; any liberating activity becomes complicit in the reproduction of its opposite. "The code is totalitarian; no one escapes it: our individual flights do not negate the fact that each day we participate in its collective elaboration". 
The point is that Baudrillard tries to describe how consumer buying "code" from the signs and meaning of the object itself. Analysis of the process where the sign stops referring to the direction of the object or signified that lies behind it, but for other signs that mix and culminate in the "murder of reality" are very chaotic, invisible, and the code becomes very "totalitarian" and Baudrillard also talks about the merger of "violence on pictures" and "explosion of meaning".

The above terminology refers to anything that is "beyond reality." According to Baudrillard, hyperreality is the most noticeable feature of the simulacra. For example, deodorant advertisement used by a woman with smooth white skin in an airport. With her style, she raises her hand while looking for the intended passengers and all of the men's eyes is directed at the woman's armpit until they almost collide and fall. Another example is a refrigerator advertisement where the mother is busy looking for stuff in the small fridge that she did not realize that her toddler can already learn how to dribble a ball. Finally, the mother decides to replace the old refrigerator with a wider refrigerator of brand " $A$ " so that she can have more time to watch her baby dribbling the ball. These examples are only to satisfy the hyperreality, namely the subject of the unreal of possible in everyday life. Roughly speaking, it can be said that hyperreality is the "lie" brought by simulacra.

Hyperreality creates a condition in which falsity mixed with the authenticity; the past mixes with the present; the fact is confused with the engineering; sign melts with the reality; lie unites with the truth/ the categories of truth, falsehood, originality, issue, reality seem to be no longer valid in such world.

"Baudrillard accepts the radical consequence of what he sees as immensely pervasive code in the late modern period. This code is clearly related to the computerization and digitization, also quite fundamental in physics, biology, and other natural sciences in which it allows for the perfect reproduction of an object or situation; this is why code can pass the real thing and open up the opportunity for the emergence of a reality called Baudrillard as hyperreality" (Lechte, 2001: 352).

The circumstance of hyperreality makes the modern society becomes excessive in the pattern of eating something with unclear essence. Most of these communities consume not because of their economic needs but because of the influence of simulation models that cause people's lifestyle to be different. They become more concerned with their lifestyle and value they uphold. Rojek (2001) in his book titled Celebrity explains that one of the changes occur in celebrity and social media is that how capitalist market turns the celebrity to be a commodity due to the society's desire as the consumer to know and 'own' everything about the celebrity. This fact is then used by the consumer society to justify whatever they do relating to the consumption practice.

Industry dominates many aspects of life; the industry produces a myriad of products ranging from primary, secondary, to tertiary. Accompanied by the power of semiotics and simulations, the distribution of product advertising becomes more vigorous, and the information technology that enables the entrepreneur to get information about what the society is currently facing, and the consumer receives information about the needs they want, but they do not need. The assumptions formed in human thought and this desire make the man cannot escape from this hyperreality state. There is a phenomenon revealed in this hyperreality term about the front stage and backstage that the individual plays a role in a drama where he plays two different properties that when met with the public will show the front step, but he will show his backstage if he is not in the public space. It can be explained that commodity products dominate the society or the individual can influence and to show the class and socioeconomic status. Today, it is considered necessary because social stratification is determined regarding each economic power.

The application of signs is always ambivalent, always functioning to avoid the dual meaning of a term: by raising other terms to bind through the signs (strength, reality, luck and so on) and to bring something to be denied and pushed back. We know that magical thinking in their myth is aimed at preventing change and history. Through the certain way, consumption that is generalized with pictures, actions, information also aim at removing the fact of signs, and to get rid of history in the signs of change and so on. 
One of the examples is an Advertisement, according to Baudrillard, destructive advertisement intensity of meaning and without clear territory. The presence of advertisements in every media either in the intersection of roads, radio, television, newspapers, magazines, and others will form an awareness of information that only occurs only on the surface. However, today's society remains fascinated by its presence. The fascination presented is related to the consumption mark, without necessarily reflecting it.

Baudrillard, as it is known in various phenomena of life (media, commodity, fashion, sexuality, music, object, art) can be interpreted in term of semiotics as a condition of the dominance of sign in various aspects of reality. Sign dominates reality as it defines the reality itself. This means that the sign as the representation if reality precisely controls the reality and claims the truth in it based on its mechanism, which is independent of the truth of reality itself. Through the free play of signs, a painting of reality is built as if it is a truth where the real truth is hidden behind it. The very dominant of sign causes the reality as its reference to sink Piliang, 2004:76).

Even now consumption can no longer be based on material activities. As in Saussure's thought of the bond between marker and sign. The point at which these sign and marker escape causing the movement of meaning to become unlimited and wild. Everything in the world has the potential to stand on its own and can exchange meaning to each other. The originality of the material becomes something that no longer needs to be pursued. In Baudrillard's thought, consumption can occur on every sign. The abundance of existing signs has the potential to be interchangeable to be attributed to the abundance of commodities present in society. Consumption has nothing to do with what we perceive as a reality, but consumption relates to systematic and unlimited ownership as a sign of the object of consumption, and in a consumer society controlled by the code of human relations is transformed into the object, especially the consumption of the object. These objects have no meaning because of their usefulness and necessity but have their meaning as a sign rather than use value or exchange rate and consumption of the signs of this object using the language we understand. Commodities are purchased as a style of expression and sign, prestige, luxury, power and so on.

So, the value of exchange in the object of consumption is no longer valid. It turns into the symbolic exchange. Sings presented in an object exchanged with another thing closer to the environment of those who consume those objects. This can be seen when the competition that occurs among upper-middle-class society.

Jean Baudrillard says that the current social order has been based on the rationality of hedonism based on the satisfaction of need and pleasure through consumption. This means that the present life of the society who have been exposed to the influence of modernization and globalization that have created a hedonistic culture in which community will perform various ways and activities that aim to give priority to pleasure in their lives. People will work to find money that will be used to buy goods that they think can satisfy the needs.

Also, those who have money will spend it for useless stuff such as organizing a party with glamorous style, doing plastic surgery so that their face will look prettier and so on. Thus, the traditional life full of the teachings about piety, simplicity, altruistic, attitude and suppression of the desire or lust has undergone many shifts in life that is based on hedonistic morality that prioritizes on excessive consumption previously known to be spread by the mass media.

\section{METHODS OF RESEARCH}

The type of the research used is qualitative research with phenomenology approach. The qualitative analysis tries to explain how people catch the meaning of an event and learn to see an event from the various perspectives (Neuman, 2000).

Phenomenology focuses its study on meaning-based society attached by the member. There are three stages of reduction according to Husserl (Hendrik, 2010:119) namely: 
- Phenomenological reduction is the screening of everyday experience of the world, to see the world in its original meaning. Or in other words, this decline is "self-cleaning" of all subjectivity that can interfere with the journey of reaching that reality;

- Eidetic reduction, according to him this stage is nothing but to discover the Eidos or the essence of hidden phenomena;

- The transcendental reduction is excluding and filtering out all observed phenomena from other phenomena. Transcendental reduction intends to find pure consciousness by eliminating empirical knowledge so that self-awareness is no longer grounded in connection with other events.

Phenomenology attempts to reveal the phenomenon as it is (to show itself) according to Ellson's self-explanation, "according to Elliston's explanation," phenomenology can mean: to let what shows itself to be seen through itself and within its boundaries, and it shows through itself "(Elliston, 1977: 279).

\section{RESULTS AND DISCUSSION}

In this research, identity does not stand alone but an integrated form of personal identity. Furthermore, characters of individual are different from each other, the uniqueness that carried by each of it shows the integrity. There are no two individuals who have the same personality even if they are twins. It is found that identity presented by Ganbattearisan group to show its existence is with its fixed members of the upper middle class with the existence demonstrated in the public sphere and the uniqueness they possess, because the specificity arises from the existence of professionalism which necessarily gives space and time which cannot be seized by anyone, indeed, in fact, this arisan is quite famous in Samarinda because its members are women who are known in the public and mass media.

Simply search on google with keyword Ganbattearisan then several profiles about them will appear immediately. They are not only advertising through online media but also offline. This group consists of various races, ethnicities, religions, and ages from different fields and settings. This group simply looks very colorful. The conversation finally came true and formed a group called "Ganbatte." A short word that is nice to hear from the Japanese term of "GanbatteKudasai" which means "Spirited up." The reason is that they are the beginning of arisan group with characters in Samarinda and similar arisan groups formed with the diverse concept.

Dr. ME, Assistant to the Provincial Secretariat is the Captain of the arisangroupd. If someones wants to join this arisan group she will be selected by her because Dr. ME has the job to maintain the exclusivity of this arisan group. According to her "Selecting good and bad friend is like selecting perfume seller and a blacksmith. Perfume seller may give your more perfume, or you can buy it from her, even if you don't buy anything you will still smell good because of her. Meanwhile, a blacksmith can give your trouble of the sparks of fire, even so, you will still get the smell of the smoke which is unpleasant most of the time." Other members are NR, the Consultant/Advisor and professional/certified translator in English and Japanese. TP, the fashion designer. The Chairman of the Organization. drg. IC, Practitioner drg, former Princess beauty. MM, the owner of Salon Japan, wife of the police office, LS, the owner of House of Beauty and Boutique. EL, the owner of Hair and makeup salon. IP, the owner of the most prominent Phone store in Samarinda. FK, Personal Assistant and Secretary of the Governor. IS, a financial officer in the State Office of Samarinda. They are all professionals in their field, and for them, arisan is the way to gather and save money in another form.

According to Imey and other members, Ganbatte is not only a group of arisan but a group of women who are active, resilient and optimistic. These are the characteristics they are expecting as self-reflection. Although they come from a various background such as beauty expert, salon owner, doctor, businesswoman, lecturer, they feel connected to each other. The members think that it is fun to hang out with friends who are the expert in different fields so that they can exchange information with each other.

Ganbatte is not an ordinary group; this is not a group where most of the members like to gossip or talk about negative things of others. Ganbatte's activity is more than just that. 
Also, the rule of this group is "not allowing its members to talk or gossip about other people, they are encouraged to come and bring happiness to others".

As already stated, no one is exclusively in only one identity. Personal identities described throughout this paper are part of the group identity. Although everyone has his or her uniqueness in their personality, she or he will keep the interest between one and another in the group whether it be cultural, hobby, life plan, and other emotional boundaries.

Every personal identity is part of the group identity. Meanwhile the group identity is the sole single identity for an individual. There is an Indonesian proverb "When in Rome, do as the Romans do.", this saying means that we should not only show someone's culture, but we also have to adapt ourselves to the culture where we currently live in because the culture has its own identity.

Concerning the consumption and lifestyle practices of the Ganbattearisan group in Baudrillard's perspective. The consumption practices done by the members are about the needs of food, fashion, electrical fashion, recreation as done by LS and IP one of the members of Ganbatte. Top class beauty treatment is done to support the appearance such as Botox Injection and increase the volume of eyelids because IP has slit eyes and she wanted to have eyelid. Some members also like to do Dental Veneer routine to boost their confidence when meeting the customers. Another case is the IS about fashion shopping; she loves to buy branded goods because she thinks that it is better to buy an expensive but durable product than purchasing cheap goods with low quality. But these members are more frugal in terms of expenses. For Indun, she likes to wear shoes and slippers, she wants to wear the Everbest brand, Bonia watches, and for hijab, she usually wears Dian Pelangi, and she trusts Erha Clinic for her cosmetics. Another member of Ganbatte named EL prefers the vehicle, and she thinks that car is the ultimate satisfaction for the one who owns it. Thus, she uses Lexus for his daily activity because it is more classy for the car category in the city. To support her appearance, she likes to wear watches, because according to EL, successful people appreciate the time and she often wears Rolex brand watch. For holidays, she rarely prefers Indonesia as the tourist destination; she likes to go to locations that are not usually visited by the tourists. For example, she just recently visited Bhutan, a country located in the valley. She even had to hire her plane to go to that country, and it cost her almost IM. There should be an exceptional pilot because the airstrip in Bhutan can only be used by the pilot with unique specification who can fly the plane to that country. EL's goal was to do devotional act in Butan because she is a Buddhist. She also often visits India, in her opinion going to India is like going to "umrah" for his Buddhist.

Another example is NR who always trusts Channel as her cosmetics derived from his grandmother and her mother. TP prefers Japanese cosmetics named Menard, and she also prefers Hammer as her car. For the members of Ganbatte, Hermes brand remains a favorite because according to them the quality is excellent and it is quite classy.

For them, fashion is one of the ways to show the constructed class identity and style is also political, in the sense that it is one of the ways in which positions and characters of are used. According to them, fashion cannot be separated from the development of the history of human life and culture. The importance of fashion in social context becomes more explicit about the status itself. Besides, clothing is an expression of personal identity, thus "selecting clothes either in-store or at home, means defining and describing ourselves" (Lurie, 1992: 5). For example, the recent event in Samarinda titled "Festival KemilauSarungSamarinda" where Ganbatte became the only arisan group to be awarded as a group that has helped to preserve the Samarinda culture.

Baudrillard explains that the current consumption practices are not only influenced by purely economic factors or based on rational choice, but there is also a cultural system and social meaning system that can direct the individual's choice of a particular commodity and show the identity. About the explanation put forward by Baudrillard and the above informant statement, it shows that to join the Ganbattearisan there must be a standard to be made by what has been chosen by ME as the Chairman of Ganbattearisan group. The selection of a member of Ganbattearisan group is part of the social meaning system that can direct the individual choice of a particular group. 
Consumer pattern caused by capitalism gives impact to mass production which then creates a culture. The culture is so attached to the community over the possession of overproduction goods raising the popular culture. Then, popular culture is already seen as a distributed sign. In his book titled The Consumer Society: Myth and Structures, Baudrillard tries to explain that the existing social structure refers to a collective social structure without neglecting individual differentiation. It is seen when the ownership of an object determines the identity of a particular individual.

The object becomes a determinant of identity that is presented through a sign that has been created. Therefore, every member of Ganbatte who wants to have a character, inevitably, consume the goods to get the built sign. The purpose of consumption is no longer to spend or utilize the use of consumer goods but to use the signs that are deliberately entered into the consumer goods by the producers through a conscious manipulation effort that is assisted by the sophistication of the mass media. For example is what has been done by IP, Baudrillard says that the consumption society is related to what they have as a sign of consumption object and the consumption society is controlled by the sign because the object is used as a sign, not as a consuming part.

\section{CONCLUSION}

Everyone always wants to show his or her existence by showing off his identity. The ultimate human personality is the identity as a human. This point is depicted in various other characters that lead to personal identities. Therefore, the identity of a person does not consist of a single identity but multi identities (Molan, 2015: 68). A person's identity becomes an issue when being exclusively singled out, and the individual will deny the other identities. The identity shown by Ganbattearisan group is the life of a narcissistic woman such as the mutual attitudes of freedom, and the implementation and consumption practices of Ganbatte's members emphasize more on the 'mark value' of the objects of industrial construction.

Martin Lindstrom in his book titled Buy Ology explains that advertisers have long assumed that logo is everything. Companies have spent thousands of hours and millions of dollars creating, engineering, sharpening, testing, and making sure their logos are stamped on our face,head and under our feet. Indeed they have been focusing on directing and motivating consumers visually for a long time. Ganbatte members always put the logo in the purchase decision because visual images will be much more efficient and memorable when combined with other senses, such as hearing and smell. It suits where they gather at Boncafe or The Grill because the two restaurants serve great views to be seen and the lively atmosphere and the aroma of the food that is present can make consumers imagine the fancy taste.

Indeed companies find something that they think is better than just throwing logos at us, involving the scent into our nose and ears. This is called Sensory Branding. Overall, it cannot be separated from the name of imaging. Imaging is the most urgent thing in the community's life covering all of the surrounding behaviors. Thus, Ganbatte members that consist of women should utilize the branding of occupation, an activity that creates money and comes from the result of their work. The reason is that all of the effort related to that thing, without going through the medium of imaging, will be perceived as something bland and futile. Thus, what is considered to be essential and unimportant to be known by everyone as the target will be become increasingly blurred. Therefore they are pleased when talking about their occupation because through this profession their image is lifted. Although they are fond of makeup, shopping and hanging out, they still have a steady job, and it makes them more confidence. If they have saved enough money or achieve enough wealth, they will have more time to have fun. Thus, in today's society, the ability to live by having fun is used as the tool to show of someone's degree or status. The more she is unbaled to work in productive tasks (leisure), the higher her degree in the society.

Ultimately the existing imagery no longer speaks of right and wrong or worthy and unworthy. But the most important of the depicted image is part of the representation of the 
happening events. Thus, in such an imaging model, any analysis or interpretation can be right and even wrong, and further mislead the public opinion goes on the same time.

Based on the overall explanations above, those things we are consuming is not the object of consumption itself but the meaning and value of the sign. Baudrillard's ideas open up a complicated question of the role of commodities play as a matter of daily living culture. However, the Baudrillard's statement that demand in a modern consumer society is merely a product of the manipulation of commodity-value signs done by the institutions through advertising and mass media, and those needs are always 'immanent' and premature.

Ganbatte with some of its members who come from the same class always share about their day-to-day life in every meeting, and they also talk about new items they have bought and the price of it. Most of the topic of the conversation includes only these things. They want to show their class to the public or their fellow members in the Ganbatte group directly. According to Assael's (1984: 252) explanation of the behavior of the Ganbatte group, that "A mode of living is identified by how people spend their time (activities), what they consider important in their environment (interest), and what they think about themselves and the world around them (opinions) ". Ganbattearisan group implements how people from the same sub-culture, social class, and job can have different lifestyles

This is in line with Baudrillard's explanation that consumption has become "...a process of significance and communication, based on the rules (code) in which consumption practices enter and take their meaning. Here, consumption is an exchange system, and correspond with language. Only the discussion of structure that can enter this stage... besides, consumption as a process of social classification and differentiation, whereby these objects/marks are ordained not only as significant differences in one code but as a corresponding value (rule) in the hierarchy... being the object of determining strength, especially the distribution of values" (Baudrillard, 2004: 61).

Thus, he wants to say that in today's society the object of consumption controls us, not the other way around. Consumers are stuck in the rhythm they make. Instead of the symbols, the prestige that we can even dissolve in the system. We often assume that consumers have the freedom to use the object, but it works the other way around now.

\section{REFERENCES}

1. Assael, H., 1984. Consumer Behavior and Marketing Action. (Second edition). Boston: Kent Publishing Company.

2. Baudrillard, J.P. 1983. Simulation, terjemahan Paul Foss, Paul Patton and Phillip Beitchman. Press Cambridge.

3. Baudrillard, J.P 2004. Masyarakat Konsumsi. Bantul: Kreasi Wacana.

4. Chaney, David. 2008. Lifestyles. Sebuah Pengantar Komprehensif. Yogyakarta: Jalasutra

5. Featherstone, Mike. Misbah Zulfa Elizabeth (Translator). 2008. Posmodernisme and Budaya Konsumen. Yogyakarta: Pustaka Pelajar.

6. Gane, Mike. 1993. Baudrillard Live. Selected Interview. London. Routledge.

7. Gilbert, Alan and Gugler J. 2007. Urbanisasi and Kemiskinan di Dunia Ketiga. Yogyakarta: PT Tiara WacanaYogya.

8. Hewwit, John P. 1984. Self and Society: A Symbolic Interactionist Social Psychology. 3rd ed. Boston: Allyn and Bacon.

9. Hjorth, Larissa. 2009. Mobile Media in the Asia-Pasific, Gender and the art of Being Mobile.London. Routledge.

10. Horkheimer and Adorno.2007.Introduction to critical theory.Yogyakarta: Pustaka Pelajar,

11. Ibrahim, Idy Subandi. 2009. Lifestyles Ecstasy: Kebudayaan Pop dalam Masyarakat Komoditas Indonesia, Yogyakarta, Jalasutra.

12. Ida, Rachmah. 2014. Metode Penelitian. Studi Media and Kajian Budaya. Jakarta. Prenada Media Group.

13. Kasali, Reinald. 2001. Membidik Pasar Indonesia: Segmentasi, Targeting and Positioning. Jakarta: Gramedia Pustaka Utama. 
14. Kellner, Douglas. 2010. Budaya Media. Cultural Studies, Identitas and Politik,. Antara Modern and Postmodern. Yogyakarta. Jalasutra.

15. Lamb, Hair \& Mc. Daniel. 2001. Pemasaran. Jakarta. Salemba Empat.

16. Lechte, John. 2001. 50 Filsuf Kontemporer. Yogyakarta: Penerbit Kanisius.

17. Michel de Certeau, 1984. The Practice of Everyday Life, trans, Steven Rendall. Berkeley. University of California Press.

18. Neuman, Lawrence W. 2000. Social Research Methods. USA: Allyb and Bacon.

19. Piliang. A. Yusuf. 2004. Dunia Yang Dilipat. TamasyaMelampauiBatasbatasKebudayaan. Bandung: Penerbit Matahari.

20. Ritzer, George, \& Barry Smart. 2014. Handbook Teori Sosial. Bandung: Nusa Media.

21. Ritzer, George. 2010. Teori Sosial Postmodern. Bantul: Kreasi Wacana.

22. Ritzer, George. 2012. Teori Sosiologi.Dari Sosiologi Klasik sampai Perkembangan Terakhir Postmodern. Yogyakarta. Pustaka Pelajar.

23. Seidman. Irving. 2006. Interviewing As Qualitative Research: A Guide for Researchers in Education and the Social Sciences. NY. New York: Teacher College Press.

24. Soemardjan, Selo and Soelaeman Soemardi. 1964. Setangkai Bunga Sosiologi. Jakarta: LP FE-UI.

25. Soerjono, Soekanto. Prof. Dr. 1987. Sosiologi Industri. Suatu Pengantar. Bandung. CV. Remaja Karya.

26. Soembodo, Benny. 2012. Ekologi Kota. Surabaya. PT. Revka Petra Media.

27. Susanto. Alfonsus.B. 2001. Potret-Potret Gaya Hidup Metropolis. Jakarta: Penerbitan Buku Kompas.

28. Sulistyo-Basuki. 2006. Metode Penelitian. Jakarta: Wedatama Widya Sastra and Fakultas IImu Pengetahuan Budaya Universitas Indonesia.

29. Veblen, Thorstein.1994. Teori Kelas Kenyamanan: sebuah studi ekonomi lembaga, Mineola, NY: Dover Publications.

30. Bagus, A.Laksana. 2013. Ribetnya Hidup Sehari Hari; Menafsir Hidup Harian Sebagai Teks Budaya.journal.unpar.ac.id/index.php/melintas/article/download/267/252. Melintas. Faculty of Theology Sanata Dharma. Yogyakarta.

31. Gordon, lan. Life is not complete without shopping: Consumption culture in Singapore. Journal of Southeast Asian Studies / Volume 37. 2003.

32. Kushendrawati, Selu Margaretha. Masyarakat Konsumen Sebagai Ciptaan Kapitalisme Global: Fenomena Budaya Dalam Realitas Sosial. Makara, Sosial Humaniora, Vol. 10, No.2, Desember 2006. FIB. UI.

33. Krishnan, Jayasree, Lifestyle - A Tool for Understanding Buyer Behavior Int. Journal of Economics and Management 5(1): 283 - 298 (2011).

34. Lawson, Rob and Sarah Todd. Consumer lifestyles: a social stratification perspective.Volume 2(3): 295-307, Journal of Marketing.London, Thousand Oaks, CA and New Delhi.

35. Plummer, Joseph T., The Concept And Application Of Life Style Segmentation. Journal of Marketing, Vol 38(1), Jan 1974, 33-37.

36. Todd, Danielle. 2012. You Are What You Buy: Postmodern Consumerism And The Construction Of Self. Hohonu. University of Hawai'i at Hilo.

37. Data penduduk kota Samarinda.http://bappeda.samarindakota.go.id/berita/baca/57, diakses 25 Februari 2016

38. Orang kaya Baru Indonesia tersebar di pedalaman. https://gaya.tempo.co/read/news/2014/08/07/108597866/orang-kaya-baru-indonesiatersebar-di-pedalaman, diakses 20 Februari 2015.

39. http://infed.org/mobi/jean-baudrillard/, diakses Desember 2016.

40. Termahal di Kaltim, Pemkot Kaket. http://www.kaltimpost.co.id/berita/detail/12955/sebulan-2-mobil-mewah-melenggang.html, diakses pada 20 Februari 2015.

41. Publikasi Arisan Ganbatte. http://samarinda.prokal.co/read/news/48-geliat-wanita-wanitametropolis-samarinda.html.

42. http://kaltim.prokal.co/read/news/69013-arisan-ganbatte, diakses pada 20 Februari 2015. 